from two sources, the inflows and the bottom deposits, and for this reason the Lake may be extremely productive. Chemical analyses (Table 2) show there has been an overall decrease in the total concentration of dissolved solids since 1958, which may be accounted for by remarkable plankton blooms, Salvinia auriculata and the expansion of the fish population during the past two years.

Limnological research at Kariba during 1961 will include such specific studies on the abundance of phytoplankton, the hydrology and chemistry, the ecology and abundance of fishes and the autecology and control of Salvinia auriculata, and will continue throughout the period of filling, which is expected to be completed in $1963 / 64$, until the Lake enters its permanent phase of development.

"Jackson, P. B. N., Kariba Studies: Ichthyology, the Fish of the Middle Zambezi (Manchester University Press, 1961).

${ }^{2}$ Edney, E. B., S. Afr. J. Sci., 55, 255 (1959). Balinsky, B. I., and James, G. V., S. Afr. J. Sci., 58, 101 (1960). Jackson, P. B. N., The New Scientist, 7,877 (1960). Crowcroft, P., ibid., 8, 933 $(1960)$.

${ }^{3}$ Jackson, P. B. N., Proc. First Fed. Sci, Congres8, Salisbury (1960). - Beauchamp, R. S. A., J. Ecol., 41, 226 (1953). Harding, D., in Jackson et al., A Report on a Fisheries Survey of Lake Nyasa (Govt. Printer, Nyasaland) (in the press).

${ }^{5}$ Beauchamp, R. S. A., Intern. Rev. Hydrobiol., 39, 316 (1939). Dubois, J. Th., Hydrobiologia, 10, 215 (1958).

\title{
OBITUARIES
}

\section{Prof. J. H. Andrew}

THE death on May 5 of Prof. John Harold Andrew, at the age of seventy-four at Ruthin Castle Hospital in North Wales, was no surprise to his friends; he had been in ill health for a number of years, and Mrs. Andrew, to whom he was devoted, had died in January. Andrew retired from the chair of metallurgy in the University of Sheffield in September 1950, having been advised medically to take this step two years before the end of his statutory period of office; he was made emeritus professor. For reasons of health and because they loved the country, he and Mrs. Andrew retired to Llandudno.

A native of Ashton-under-Lyne, he was educated at Bickering House School, Birkdele, and the University of Manchester, where he graduated in chemistry in 1907 and was awarded the degree of D.Sc. in 1915 . In 1910 he was appointed Research Fellow and demonstrator at Manchester, where he was a Dalton Scholar. After six years as head of the Metallurgical Research Department of Sir W. G. Armstrong Whitworth and Co., Ltd., he was, in 1920, appointed professor of metallurgy at the Roysl Technical College, Glasgow, succeeding the late Dr. C. H. Desch. With an established reputation in the field of metallurgy, he again succeeded Desch as professor of metallurgy and dean of the Faculty of Metallurgy at Sheffield in 1932.

Andrew was an original member of the Institute of Metals, was elected a member of the Iron and Steel Institute in 1911 and was a founder Fellow of the Institution of Metallurgists. He was a prominent member of the Heterogeneity of Steel Ingots, Alloy Steel Research and Steel Castings Research Commit. tees of the Iron and Steel Institute, all which have now been incorporated in the committees of the British Iron and Steel Research Association.

During his thirty years as a professor at Glasgow and at Sheffield he published a very large volume of research covering extensive fields of interest. As a director of research, his fertility of mind, his unorthodox points of view and his continuing encouragement were a source of inspiration to many postgraduate students. The number of joint papers he published bears testimony to his great sense of loyalty and co-operation.

Andrew was not only well known for his research work. His administrative ability and great talent for organization brought about a striking development of the Departments of Metallurgy at Glasgow and at Sheffield. In recognition of his work in metallurgy, he was awarded in 1949 the Bessemer Gold Medal of the Iron and Steel Institute, an honour which he richly deserved. Shortly after his retirement in 1950, a group of Sheffield steel firms established the J. H. Andrew Senior Research Fellowship tenable in his old department, where a laboratory is also named after him.

To his staff, from the most senior to the humblest laboratory assistant, he was a friend who, with his sympathetic understanding and lively sense of humour, made difficulties seem trivial.

Prof. and Mrs. Andrew leave friends in Glasgow and Sheffield in all walks of life who will not forget their unfailing kindness, courtesy and generous hospitality. It was the hope that some of the happiness they had given should have been theirs in retirement; unfortunately, their retirement was sadly marred by continued ill-health. W. R. MadDocks

\section{Dr. H. Horn af Rantzien}

ON September 15, 1960, Dr. Henning Horn af Rantzien was killed at Montmorency, France, by a stone which slipped while, in the company of his wife and a French friend and colleague, he was examining a quarry for fossil plant remains.

Henning Horn graduated at Stockholm and, from 1945 on, held research positions in the Botany and Palæobotany Departments at the Riksmuseum, Stockholm, and later in the Geology Department of the University of Stockholm, where he taught historical geology. During 1948-51, he was an editor of Svensk Botanisk Tidskrift. At the time of his death, he was pursuing a long-term research programme on the taxonomy and phylogeny of the Charophyta, a work to which he had devoted most of his time during the past ten years and which had carried him, at the age of thirty-eight, to a leading position in the field of mieropalæontology.

Those who knew him only as a highly specialized palæobotanist may be surprised to learn that $a$ great part of his early writings were on recent vaseular plants. He paid particular attention to the taxonomy and distribution of Phleum, Pleurospermum, and the West African and Latin American species of Mayaca, Najas, and Triglochin. Simultaneously, he revised the American Nitellae and thoroughly reviewed the literature available on all American Charophyta. In 1951, following extensive field-work, he published an ecological-geographical study of aquatic and amphibious plant associations (including bryophytes 